\title{
ERRATUM
}

M. Raffel $\cdot$ H. Richard $\cdot$ K. Ehrenfried

B. Van der Wall $\cdot$ C. Burley $\cdot$ P. Beaumier

K. McAlister $\cdot$ K. Pengel

\section{Recording and evaluation methods of PIV investigations on a helicopter rotor model}

Published online: 1 March 2006

(C) Springer-Verlag 2006

\section{Experiments in Fluids (2004) 36(1):146-156}

In the original publication of this article, there are typographical errors in the first equation on page 154 . We apologize for this mistake. The correct equation is:

$e_{u, \text { rel }} \leqslant W_{\max } / U_{\max } \times 3 /(\Delta Z \times M) \times e x$,
Accordingly the following sentences should read "Therefore, the measurement error can be reduced by minimizing any one of three terms: $W_{\max } / U_{\max }$, $3 /(\Delta Z \times M)$, and ex."

The online version of the original article can be found at http:// dx.doi.org/10.007/s00348-003-0689-7

M. Raffel $(\bowtie) \cdot H$. Richard $\cdot$ K. Ehrenfried

Institut für Aerodynamik und Strömungstechnik, DLR, Göttingen, Germany

E-mail: markus.raffel@dlr.de

B. Van der Wall

Institut für Flugsystemtechnik, DLR, Braunschweig, Germany

C. Burley

NASA Langley Research Center, Langley, VA, USA

P. Beaumier

ONERA, Chatillon, France

K. McAlister

US Army AFDD, NASA Ames Research Center, Moffett Field,

CA, USA

K. Pengel

Large Low Speed Facility LLF, DNW, Nordostpolder,

The Netherlands 